\title{
Reconsidering agricultural credits and agricultural productivity nexus: Evidence from a global representative panel data
}

\author{
Dicle Ozdemir ${ }^{1}$ \\ ${ }^{1}$ Affiliation not available
}

March 2, 2022

[1] Faculty of Economics and Administrative Sciences, Mugla Sitki Kocman University, 48000 Mugla, Turkey. E-mail: dicleozdemir@mu.edu.tr

\begin{abstract}
Access to credit has been a key component in protecting agriculture sector against uncertainties and climaterelated shocks. Agricultural credits may also increase both agribusiness sectors' and farming-related commercial activities' exposure to world markets. The purpose of this study is to investigate the short-run and long-run effects of agricultural credits on agriculture value added using some other control variables such as foreign direct investments and government expenditures. Employing combined autoregressive distributed lag (ARDL) panel approach and Dumitrescu-Hurlin Panel Causality tests with global data from 2000-2018, we found that credits to agriculture affects agricultural productivity positively in the long-run; when agricultural credits increase by $1 \%$, agricultural productivity will increase by $0.19 \%$; that is, an increase in the amount of credits to agricultural sector leads to a remarkable increase in value-added agriculture, while FDI and government size both reduce agricultural productivity across countries. The findings of the pairwise causation test indicate that there exists bidirectional causal links among almost all variables, validating a feedback hypothesis revealed among agricultural productivity, credit to agriculture, FDI, government expenditures and inflation.
\end{abstract}

Key words: agricultural productivity; agricultural credits; foreign direct investment; government expenditures

\section{Introduction}

Rapid urbanization, climate change and disaster risks place pressure on agricultural production and baseline vulnerability. While there has been a steady increase of population growth during the past decade, it is very important for future generations to be able meet sufficient quantity of appropriate food available in an inclusive and sustainable manner. Obviously, food security and sustainability can be achieved by increasing productivity in agricultural production and finding alternative sustainable ways to produce more food on less land. In addition to parameters such as fertilizer, irrigation, medicine, seed, labor, soil, tool-machine and technology usage, agricultural financing with low-interest for elimination of farmers ${ }^{6}$ financial constraints to carry out their activities more comfortably and efficiently is vital to sustainable rural development, particularly for the least developed countries. Besides, advances in technology within agriculture have forced businesses to use more modern inputs and increased their capital requirements to access new knowledge, investments and innovative farming methods. Furthermore, price risks due to the low elasticity of demand in agricultural products can result in uncertainties in the incomes of producers and thereby, necessitate the use 
of policy tools such as measures to support producer prices, subsidies for agricultural inputs, and short-run financing loans to producers (Thompson, 1916; Leatham and Hopkin, 1988; Binswanger, 1989; Tweeten and Zulauf, 2008).

First and foremost, agricultural sector plays a strategic role in reaching social welfare development through spreading employment and income gains. Coinciding with steady growth in real wages, increasing productivity growth in all sectors is critical to increase domestic demand. To increase agricultural productivity, as well as inefficient production methods, labor market distortions should also be prevented. Besides, in agricultural development process, agricultural support policies such as cash subsidies, credits, tax benefits make agriculture competitive, improve investments, increase resource allocation and profitability, and thereby, continue farming in a sustainable manner (Kahan, 2013). Specifically, stimulating agricultural credit policies ensure the quantity and continuity of agricultural production by providing input to higher productivity gains. Especially, the existence of mostly small sized farms in low-income countries, most of which are family-owned and operated, the timing, techniques and conditions of harvesting, adopting new technology and diversifying their production are responsible for agricultural credit demand. Consequently, the uncertainties inherent in agricultural production raises the possibility that the producers do not always get the expected income and lead to reduced productivity by increasing vulnerability (Kahan, 2013; Rajan and Ramcharan, 2015).

The main challenge for developing countries is to improve their agricultural credit systems. For those countries, first and foremost, access to credit, especially for small-sized family farms, needs to be improved. Generally, lending to agricultural sector can be classified into mainly two types according to their intended use: Short-run or farm operating loans to help with the day-to-day expenses and investment loans to support agricultural enterprises to finance their investment expenses (Salami and Arawomo, 2013). Another aspect that deserves attention is the relationship between the agricultural credit and agricultural growth, even its impact on economic growth. As a matter of fact, agricultural sector has continued to show its important role as a "buffer sector" in the economy by providing employment during economic downturns in other sectors. However, above and beyond this, the ability of credit to induce agricultural productivity is also an issue for many developed countries worldwide. Besides this, access to adequate credit affects farm output by contributing to sustainability of farming systems and technology. Since managing risk to stabilize farm income is an important aspect of farming business, access to credit is a key component in protecting farmers against uncertainties. That is, easy availability and access to credit increases farmers and entrepreneurs lead to more diversified options to undertake new investments. One of the arguments for the contribution of agricultural credits on agricultural productivity by Braverman and Guasch (1986) is that agricultural loan interest rate should not be market rate, otherwise these types of programmes may result in some kind of subsidy and income transfer; that is, since income transfer and subsidy is proportional to the size of loan, larger landholders and larger farms receive larger income transfers and subsidies. However, it is crucial to determine to what extent financing of agricultural sector, especially through increasing the availability of bank credits to agricultural businesses and farmers have an impact on agricultural productivity. But more importantly, to what extent should we consider that agricultural financing may be more effective in contributing to higher agricultural productivity as well as stimulating growth? Going one step further, do making efforts to subsidize agricultural credits in developing countries and providing credit cheaper and easier to finance new technology adoption give an opportunity to those countries to promote rural development rapidly increasing agricultural output and productivity?

A substantial number of recent studies were devoted to investigating the effects of agricultural credits on agricultural productivity. As regards agricultural productivity, a great deal of research (Siriram, 2007; Das et al., 2009; Ali et al., 2014; Misra et al., 2016; Rehman et al., 2017; Seven \&Tumen, 2020; Tuan Anh et al., 2020; Chandio et al., 2021, Manoharan \& Varkey, 2021) identified the role of credits on agricultural productivity. While some of these studies used farm-level data, some of them has identified and addressed linkages focusing specifically on country-level data. For instance, Chandio et al. (2017) provided evidence on the positive impact of formal credit on sugarcane productivity with a farm-level data for Pakistan. Rehman et al. (2017) did a discrimination among loan types using time series data and concluded that total food production, loan disbursed by Modern agriculture technology machinery and Agriculture loans in Pakistan 
(ZTBL) and the total loan disbursed by various institutions had a positive and significant influence on the agricultural gross domestic product whereas cropped area and cooperatives loan had a negative but insignificant influence on the agricultural gross domestic product using time series data in Pakistan. Misra et al. (2016) observed a positive impact of the intensity of agricultural credit on total factor productivity in agriculture under state-level panel model for the Indian economy. A more comprehensive study by Seven and Tumen (2020) used country-level data covering 104 countries for the 1991-201 period. Accordingly, agricultural credit expansion contributes to high agricultural growth rates in almost all countries; however, this positive effect may vary according to their level of development. To the best of our knowledge, no prior work has yet been carried out to investigate the nexus between agricultural credits and agricultural value added as a proxy for agricultural productivity under a heterogenous panel cointegration and panel autoregressive distributed lag (ARDL) approach.

In the discussion of the role of agricultural credits in agricultural productivity both in short-run and long-run, the ARDL of pooled mean group (PMG), mean group (MG) and dynamic fixed effects (DFE) approaches are employed using a dataset comprising 53 countries in the period from 2000 to 2018. FMOLS (Fully Modified OLS) and Dynamic OLS (DOLS) and panel pairwise causality tests are used as robustness tests. According to this narrative, we are interested in studying the effect of agricultural credits on agricultural productivity with inflation, net foreign direct investments and general government total expenditures as our control variables to avoid omitted variable bias.

The rest of this study is structured as follows: section 2 presents the methodology; section 3 presents the data; empirical results are summarized in section 4 followed by conclusion in section 5 .

\section{Empirical Methodology}

The aim of this empirical analysis is to investigate the short-run and long- run effects of agricultural credits on agricultural productivity by considering a global sample of 53 countries over the period 2000-201811The countries in the panel are listed in Appendix A.. We initially present the conceptual framework that we follow and then outline the statistical approach that we implement to estimate the long-run equilibrium parameters.

Before the estimation, it is necessary to investigate the characteristics of the cross sections and time series, as well as to control for the existence of specificities which may lead to inconsistent and incorrect results. In this context, a set of preliminary tests should be performed before estimating the model of interest as Variance Inflation Factor (VIF) to check for the existence of multicollinearity, Cross-section Dependence (CSD) test (Pesaran, 2004) to account for serial correlation of an unknown form in the error term, second generation unit root test (CIPS-test) (Pesaran, 2007) to test the stationarity of the data, and finally, second generation cointegration test (Westerlund, 2007) to check the order of integration of the variables under consideration for establishing long-run relationship among them.

Based on the results of these tests, we consider a heterogeneous dynamic panel model to estimate the relationship between agricultural credit and agricultural productivity. A combined autoregressive distributed lag (ARDL) panel approach, namely, the Mean group (MG) developed by Pesaran and Smith (1995), the Pooled mean group (PMG) developed by Pesaran et al. (1999) and the Dynamic Fixed Effect (DFE) estimator to estimate the short-run and long-run linkages between agricultural value added and agricultural productivity with other control variables.

Pesaran et al. (1999) developed two estimators to estimate the panel ARDL model: MG (Mean Group Estimation) and PMG (Pooled Mean Group Estimation). The MG estimator places no restrictions on the coefficients in the long-run. PMG approach, associated with pooling and averaging of the coefficients over the cross-sectional units, allows a greater degree of parameter heterogeneity then the usual estimator procedures by imposing common long-run relationship across countries while allowing heterogeneity for the short-run. In other words, PMG restricts the long-run coefficients but allows the constants, error term variances, and short-run coefficients to vary. Therefore, PMG allows short-run coefficients and error variances to vary across different groups while assuming a homogeneous long-run relationship between dependent and explanatory 
variables (Tong et al., 2016). By contrast, DFE model further limits the speed of adjustment coefficient and the short-run coefficient to be the same or equal and subject to the bias between the error term and the lagged dependent variable. However, the model features country-specific intercepts allowing different intercepts and groups.

As shown in Pesaran and Shin (1996), the aim of panel ARDL approach is to estimate the relationship between agricultural productivity and agricultural credit and can be specified by the following equation:

$Y_{\mathrm{it}}=\sum_{j=1}^{p} \beta_{i, j} Y_{i, t-j}+\sum_{j=0}^{q} \gamma_{i, j} X_{i, t-j}+\mu_{i}+\varepsilon_{\mathrm{it}}(1)$

By rearranging terms such as:

$Y_{\mathrm{it}}=\varnothing_{i}\left(Y_{i, t-1}-\theta_{i} X_{i, t}\right)+\sum_{j=1}^{p-1} \beta_{\mathrm{ij}}^{\prime} Y_{i, t-j}+\sum_{j=0}^{q-1} \gamma_{\mathrm{ij}}^{\prime} X_{i, t-j}+\mu_{i}+\varepsilon_{\mathrm{it}}(2)$

with $\mathrm{i}$ and $\mathrm{t}$ representing country and time respectively, $\mathrm{Y}$ is the agriculture, forestry, and fishing value added as a percentage of GDP, $X_{i, t}$ is a $k x 1$ vector of explanatory variables containing the credit to agriculture, net foreign direct investments as a percentage of GDP, annual rate of changes in CPI (\%) and general government total expenditure as a percentage of GDP, $\varnothing_{i}$ is the group-specific speed of adjustment coefficient, $\theta_{i}$ is the long-run coefficients of explanatory variables, $\mathrm{ECT}=\left[Y_{i, t-1}-\theta_{i} X_{i, t}\right]$ is the error correction term and finally, $\beta^{\prime}$ and $\gamma^{\prime}$ are represent the short run

coefficients linking agriculture, forestry, and fishing value added with its past values and the variables of interest $X_{i, t}$

Further, one more estimation technique is employed as a part of robustness check. The Dynamic Ordinary Least Square (DOLS) proposed by Stock and Watson (1993) and later extended by Kao and Chiang (2001)22The mathematical derivation of the model can be found in Stock and Watson (1993).. DOLS method can be applied with mixed and higher orders of integration and frequently used in estimating long-run nexus for heterogeneous panel by correcting simultaneity, endogeneity, serial correlation and small sample bias among the regressor 33Fully Modified OLS (FMOLS) is also commonly used to check the robustness of DOLS results in the literature; however, this approach essentially requires that all variables must have the same integration order (Yahyaoui and Bouchoucha, 2021). As Kao and Chiang (2001) proposed, DOLS outperforms FMOLS estimators in terms of mean biases. Ali et al. (2017) notes that the most significant benefit of DOLS is that the test considers the mixed order of integration of variables in the cointegration framework. (Stock and Watson, 1993, Masih and Masih, 1996; Kumar et al., 2021).

\section{Data}

An annual balanced panel data set of 53 countries over the 2000-2018 period was used. The data for a selection of countries are drawn from the World Development Indicators (WDI) database provided by the World Bank (2019) and listed in Appendix A. The descriptions of the variables used in this study are presented in Table 1. The selection of the countries and time period is limited by data availability. Agriculture, forestry, and fishing value added series (AGV), the output of the agricultural sector less the value of intermediate inputs as identified by FAO statistical annex, were used as a proxy for agricultural productivity44For more information, please seehttps://www.fao.org/3/a0050e/a0050e10.htm. AGC is the Credit to agriculture, forestry and fishing, in constant LCU, INF is Inflation as the annual percentage change in consumer prices, FDI is the net foreign direct investments as a percentage of GDP, INF is the annual rate of changes in CPI (\%) and GOV is the general government total expenditure as a percentage of GDP. AGV and AGC are converted into natural logarithm for consistent and reliable empirical results. As it can be seen on Figure 1., there is a strong correlation between agriculture productivity and agricultural credits.

Table 1. Variables' description and summary statistics

Descriptive Statistics

Variables Description

Obs. 
Descriptive Statistics

\begin{tabular}{lll}
\hline LAGV & Natural logarithms of Agriculture, forestry, and fishing, value added, in constant LCU. & 1007 \\
LAGC & Natural logarithms of Credit to agriculture, forestry and fishing, in constant LCU. & 1007 \\
FDI & Net inflows (\% of GDP) & 1007 \\
GOV & General government total expenditure (\% of GDP) & 1007 \\
INF & Inflation, consumer prices (annual \%) & 1007
\end{tabular}

Notes: Obs. denotes the number of observations; Std. Dev. is the Standard Deviation; Min. and Max. are the minimum, and maximum values, respectively; and (L) denotes variables in natural logarithms. The results are reported only three digits after decimals to avoid space consumption.

\section{Hosted file}

image1.emf available at https://authorea.com/users/462994/articles/558233-reconsideringagricultural-credits-and-agricultural-productivity-nexus-evidence-from-a-globalrepresentative-panel-data

Figure 1. Correlation between agricultural productivity and agricultural credits (2000-2018)

For the purpose of a comprehensive analysis and to investigate the contribution of agricultural credits to agricultural productivity, we employ the following equation as the basic model:

$\mathrm{LAGV}_{\mathrm{it}}=\alpha_{0}+\alpha_{1} \mathrm{LAGC}_{\mathrm{it}}+\alpha_{2} \mathrm{FDI}_{\mathrm{it}}+\alpha_{3} \mathrm{GOV}_{\mathrm{it}}+\alpha_{4} \mathrm{INF}_{\mathrm{it}}+\mu_{i}+\varepsilon_{\mathrm{it}}(3)$

Since ignoring cross-sectional dependence of errors may have serious consequences, such as unbiasedness, consistency of standard panel estimators and incorrect statistical inference, VIF and CSD tests should be applied first, such as the CSD test developed by Pesaran (2004) followed by panel unit root tests, panel cointegration tests, MG-PMG-DFE estimations, DOLS estimation test for robustness check and panel causality test.

\section{Results}

\section{Preliminary tests}

To select most appropriate technique to investigate short and long run relationships using panel series methods, it is crucial to assess the characteristics of the variables. Before setting up the empirical model, we test whether multicollinearity problem and cross-section dependence among the variables exist. The variance inflation factor (VIF) is traditionally applied to diagnose the possible existence of multicollinearity with the Cross-section Dependence (CSD-test) (Pesaran, 2004) to check the existence of cross-section dependence among the variables. The null hypothesis for the CSD-test is the presence of CSD. It can be visibly seen from the results of the VIF test present in Table 2 that all of the variables are lower than the benchmark of 5.0 , supports that multicollinearity is far from being a concern. The null hypothesis for the CSD-test is not rejected in most cases (the exception being LAGV in first differences); that is the CSD-test shows the presence of cross-sectional dependence in most cases11The Pesaran and Yamagata (2008) slope homogeneity test results are not reported here to save space. According to our findings, the slope coefficients are heterogeneous in the cross-sectional dimension..

Table 2. Variance Inflation Factor (VIF) and Cross-section Dependence (CSD)Test

\begin{tabular}{llllll}
\hline Variables & VIF & 1/VIF & CD Test & Corr & Abs (corr) \\
\hline LAGV & n.a. & n.a. & $71.16^{* * *}$ & 0.440 & 0.577 \\
LAGC & 1.17 & 0.853 & $25.24^{* * *}$ & 0.156 & 0.541 \\
FDI & 1.07 & 0.933 & $17.07^{* * *}$ & 0.106 & 0.260 \\
GOV & 1.01 & 0.985 & $13.42^{* * *}$ & 0.083 & 0.359
\end{tabular}




\begin{tabular}{llllll}
\hline Variables & VIF & 1/VIF & CD Test & Corr & Abs (corr) \\
\hline INF & 1.11 & 0.901 & $53.54^{* * *}$ & 0.331 & 0.399 \\
MEAN VIF & 1.09 & & & & \\
DLAGV & n.a. & n.a. & 1.24 & 0.008 & 0.213 \\
DLAGC & 1.00 & 0.998 & $2.15^{* *}$ & 0.014 & 0.202 \\
DFDI & 1.00 & 0.996 & $10.37^{* * *}$ & 0.066 & 0.216 \\
DGOV & 1.13 & 0.884 & $12.43^{* * *}$ & 0.079 & 0.217 \\
DINF & 1.13 & 0.884 & $54.78^{* * *}$ & 0.348 & 0.400 \\
MEAN VIF & 1.07 & & & & \\
\hline
\end{tabular}

Notes: $* * *, * *$ denotes statistically significant at $1 \%$ and $5 \%$ level, respectively. (L and DL) denote variables in natural logarithms and first-differences of logarithms, respectively. The results are reported only three digits after decimals to avoid space consumption.

Due to the presence of cross-sectional dependence, an extension of Im, Pesaran, and Shin (2003) unit root test, second-generation unit root tests were applied in order to detect the integration orders of the variables. The CIPS test was performed, and the results can be seen in Table 2. Considering the null hypothesis for CIPS test is, series is I(1), by analysing the results, we can conclude that all variables, except LAGV and LAGC and GOV with trend, are I(1), confirming that none of the series is $\mathrm{I}(2)$.

Table 3. 2nd generation unit root test (CIPS-test).

\begin{tabular}{llll}
\hline & & 2nd generation unit root test & 2nd generation unit root test \\
\hline & & Pesaran $(2007)$ Panel Unit Root test (CIPS) (Zt-bar) & Pesaran $(2007)$ Panel Unit Root test (CIPS) (Zt \\
& & Without trend & With trend \\
Variables & Lags & Zt-bar & Zt-bar \\
LAGV & 1 & -1.319 & 2.251 \\
LAGC & 1 & $-3.344^{* * *}$ & 0.047 \\
FDI & 1 & $-2.626^{* * *}$ & $-1.879^{* *}$ \\
GOV & 1 & $-1.890^{* *}$ & -0.059 \\
INF & 1 & $-6.501^{* * *}$ & $-5.561^{* * *}$ \\
DLAGV & 1 & $-10.769^{* * *}$ & $-9.221^{* * *}$ \\
DLAGC & 1 & $-6.473^{* * *}$ & $-3.826^{* * *}$ \\
DFDI & 1 & $-13.662^{* * *}$ & $-10.672^{* * *}$ \\
DGOV & 1 & $-8.218^{* * *}$ & $-6.089^{* * *}$ \\
DINF & 1 & $-13.446^{* * *}$ & $-9.636^{* * *}$ \\
\hline
\end{tabular}

Notes: ${ }^{* * *},{ }^{* *}$ denote statistically significant at $1 \%$, and $5 \%$ level, respectively; DL denotes variables in natural logarithms and first-differences of logarithms respectively. The null for the CIPS test is: series are I(1). The results are reported only three digits after decimals to avoid space consumption.

\section{Panel cointegration tests}

\section{Westerlung cointegration (cointtest)}

As the next step, we estimate Westerlund's (2008) second generation panel cointegration test to investigate the existence of the cointegration relationship among the series. The advantage of this procedure is that it is valid even while variables are integrated with different orders as long as the dependent variable is ?(1). We perform cointegration tests both with a trend and trend and demean, as presented in Table 4. Based on Westerlund cointegration tests, the results provide stronger evidence of cointegration relationship among 
the variables; that is, there exists a long-run relationship among the variables in this study.

Table 4 Westerlund Cointegration Test Results

\begin{tabular}{|c|c|c|c|c|c|c|}
\hline & With Trend & With Trend & $\begin{array}{l}\text { With } \\
\text { demean }\end{array}$ & $\begin{array}{l}\text { With } \\
\text { demean }\end{array}$ & $\begin{array}{l}\text { With } \\
\text { demean and } \\
\text { trend }\end{array}$ & $\begin{array}{l}\text { With } \\
\text { demean and } \\
\text { trend }\end{array}$ \\
\hline & $\begin{array}{l}\text { Variance } \\
\text { ratio }\end{array}$ & $\mathrm{p}$-value & $\begin{array}{l}\text { Variance } \\
\text { ratio }\end{array}$ & p-value & $\begin{array}{l}\text { Variance } \\
\text { ratio }\end{array}$ & $\mathrm{p}$-value \\
\hline $\begin{array}{l}\text { Ho: No } \\
\text { cointegration } \\
\text { Ha: All panels } \\
\text { are } \\
\text { cointegrated }\end{array}$ & 1.12 & 0.13 & $2.61^{* * *}$ & 0.00 & $3.30^{* * *}$ & 0.00 \\
\hline $\begin{array}{l}\text { Ho: No } \\
\text { cointegration } \\
\text { Ha: Some } \\
\text { panels are } \\
\text { cointegrated }\end{array}$ & $1.67^{* *}$ & 0.04 & $6.81^{* * *}$ & 0.00 & $1.77^{* *}$ & 0.03 \\
\hline
\end{tabular}

Notes: $* * *, * *, *$ shows $1 \%, 5 \%$ and $10 \%$ of significance level, respectively. The results are reported only three digits after decimals to avoid space consumption.

Dynamic panel ARDL tests

PMG-DFE-MG

The results from the long-run and short-run estimations under the PMG estimator, MG estimator and DFE estimators from Table 5. along with the Hausman h-test from Table 6. to measure the comparative efficiency and consistency among them are shown in Table 5 and Table 6, respectively11All mean group regressions are implemented with the Stata module xtmg (Eberhardt, 2012).. The MG models allows for heterogeneity in short- and long-run parameters. The PMG allows for short-run differences, while restricting long-run equilibrium to be homogenous across countries. Finally, the DFE model assumes both the long- and shortrun coefficients to be homogeneous (Pesaran et al., 1999; Gemmell et al., 2016). Furthermore, the Hausman model specification tests are applied to compare PMG with both MG and DFE. The results of the Hausman test indicate that the null hypothesis should not be rejected, suggesting that the PMG results are more appropriate than both MG and DFE and the simultaneous equation bias is minimal for these data (Pesaran et al., 1999). Consequently, we rely on the estimates obtained with the favorable PMG approach.

Table 5. Long-run and short-run estimator

\begin{tabular}{llllllll}
\hline & Variable & MG & MG & PMG & PMG & DFE & DFE \\
\hline \multirow{4}{*}{ Long-Run Equation } & & Coef. & S.E. & Coef. & S.E. & Coef. & S.E. \\
& LAGC & -0.064 & 0.123 & $0.196^{* * *}$ & 0.014 & $0.118^{* * *}$ & 0.027 \\
& FDI & -0.010 & 0.076 & $-0.004^{* * *}$ & 0.001 & 0.005 & 0.003 \\
& GOV & $-0.010^{* * *}$ & 0.058 & $-0.008^{* * *}$ & 0.001 & 0.000 & 0.005 \\
& INF & -0.005 & 0.018 & $-0.003^{* *}$ & 0.001 & -0.004 & 0.003 \\
& ECT & $-0.484^{* * *}$ & 0.059 & $-0.215^{* * *}$ & 0.039 & $-0.175^{* * *}$ & 0.017 \\
& D(LAGC) & -0.053 & 0.058 & -0.030 & 0.044 & -0.003 & 0.008 \\
& D(FDI) & -0.002 & 0.004 & -0.001 & 0.001 & -0.000 & 0.000 \\
& D(GOV) & 0.002 & 0.002 & $-0.004^{* *}$ & 0.001 & $-0.004^{* * *}$ & 0.001 \\
& D(INF) & 0.001 & 0.002 & -0.000 & 0.001 & -0.000 & 0.000
\end{tabular}




\begin{tabular}{llllllll}
\hline Variable & MG & MG & PMG & PMG & DFE & DFE \\
\hline C & $11.14^{* * *}$ & 1.376 & $4.745^{* * *}$ & 0.853 & $4.163^{* * *}$ & 0.415 \\
\hline
\end{tabular}

Note: $* * *, * *, *$ shows $1 \%, 5 \%$ and $10 \%$ of significance level, respectively. The results are reported only three digits after decimals to avoid space consumption.

Based on PMG-ARDL $(1,1,1,1)$ results, Table 5 shows that, for long-run, the estimated coefficients of all variables, also known as elasticities, are all statistically significant. However, only credits to agriculture affects agricultural productivity positively. Furthermore, the elasticity of credit to agriculture is the highest one with respect to others; that is, agricultural credits have greatest impact on agricultural productivity. In broad terms, a $1 \%$ increase in agricultural credits leads to $0.19 \%$ increase in agricultural productivity across countries; that is, an increase in the amount of credits to agricultural sector leads to a remarkable increase in value-added agriculture. On the other hand, FDI and government size both reduce the agricultural productivity across countries, suggesting that both FDI and government expenditures harm agriculture businesses significantly. The reason behind this inverse association may be that FDI promotes migration from rural to urban as creating jobs in urban areas with higher wages which encourages workers in rural areas to migrate (Ben Slimane et al., 2016). Similarly, government expenditures leave less for private investments in physical capital both in the short and long-run, which ultimately leads to underinvestment of agricultural products, even in export-based goods (Anríquez et al., 2016, Lopez et al., 2017). Agricultural productivity, as expected, also moves in the opposite direction to inflation, conceding that high input prices and cash flow problems for agribusiness sectors and farmers results in low production. The sign of the short-run dynamic impacts of these variables are significant only for government expenditures. Accordingly, the error correction parameter for PMG is significant and negative for GOV, which indicates government expenditures discourages agricultural productivity even in the short-run. Intuitively, as reported by FAO (2021), the reduction in the share of agriculture in government expenditures in all regions except Asia between 2001 and 2009 might have deleterious effect on agricultural and rural development both the short and the long run.

Table 6. Hausman test results to select model between MG, PMG and DFE

Ho: difference in

coefficients not

systematic MG and PMG

DFE and PMG

DFE and MG

\begin{tabular}{llll}
\hline chi2(4) & 1.89 & 0.00 & 0.00 \\
p value & 0.75 & 1.00 & 1.00 \\
Decision & The Ho of homogeneity & The Ho of homogeneity & The Ho of homogeneity \\
& cannot be rejected & cannot be rejected & cannot be rejected \\
Appropriate model & PMG & PMG & MG \\
\hline
\end{tabular}

Notes: ${ }^{* *},{ }^{* *},{ }^{*}$ shows $1 \%, 5 \%$ and $10 \%$ of significance level, respectively PMG is efficient estimation than MG under null hypothesis. PMG is efficient estimation than DFE under null hypothesis. MG is efficient estimation than DFE under null hypothesis.

\section{Robustness of long-run estimation approach}

In order to evaluate the robustness of the analysis developed so far, we have applied only Panel Dynamic OLS (PDOLS), proposed by Kao and Chiang (2001), rather than FMOLS (Fully Modified OLS) due to the mix order of integration as a part of robustness check to PMG model11As mentioned previously, FMOLS can only be used for the long-run estimates of I(1) variables.. The advantage of DOLS procedure is that it is free of endogeneity and serial correction problem in the heterogeneous panel cointegrated series while allowing for individual heterogeneity through different short-run dynamics, individual-specific fixed effects and 
individual-specific time trends (Mark and Sul, 2003; Luis et.al., 2007). Based on the existence of cointegration relationship among the variables, the long-run coefficients of the regressors on agricultural productivity was estimated using the weighted DOLS estimator. All the variables are significant; nevertheless, the signs of FDI and GOV are not consistent with that of the PMG estimation. Results are displayed in Table 7, indicating that a $1 \%$ increase in credits to agriculture enhances almost $0.11 \%$ agricultural productivity.

Table 7. Results of DOLS (Dependent variable: LAGV)

\begin{tabular}{lllll}
\hline Variable & DOLS & DOLS & DOLS & DOLS \\
\hline & Coefficient & Std. Error & t-value & Prob \\
LAGC & $0.111^{* * *}$ & 0.008 & 12.612 & 0.000 \\
INF & $-0.008^{* * *}$ & 0.001 & -8.058 & 0.000 \\
FDI & $0.006^{* * *}$ & 0.001 & 5.829 & 0.000 \\
GOV & $0.006^{* * *}$ & 0.001 & 5.291 & 0.000 \\
Adjusted R-squared & 0.999 & & & \\
\hline
\end{tabular}

Notes: $* * *, * *, *$ shows $1 \%, 5 \%$ and $10 \%$ of significance level. The results are reported only three digits after decimals to avoid space consumption. As suggested by Pedroni (2000) and Kao and Chiang (2001) heterogeneous panels, pooled weighted DOLS were used in this study. Fixed leads and lags specification $(\mathrm{lead}=1, \operatorname{lag}=1)$ was chosen.

Finally, to reach more parsimonious conclusion, we, therefore, proceed by investigating the existence of a causality between agricultural productivity and its determinants using a pairwise causation test by Dumitrescu \& Hurlin (2012). Estimates for the Pairwise Dumitrescu-Hurlin panel causality test are shown in Table 8. The findings of the pairwise causation test indicate that there exists bidirectional causal links among almost all variables, validating a feedback hypothesis revealed among agricultural productivity, credit to agriculture, FDI, government expenditures and inflation.

Table 8. Pairwise Dumitrescu-Hurlin panel causality test

\begin{tabular}{llll}
\hline Causal Relationship & W stat. & Z-bar stat. & Z-bar tilde stat. \\
\hline LAGC - LAGV & 8.442 & $11.434^{* * *}(0.000)$ & $2.095^{* *}(0.036)$ \\
LAGV - LAGC & 9.105 & $13.141^{* * *}(0.000)$ & $2.664^{* * *}(0.007)$ \\
INF - LAGV & 1.468 & $2.412^{* *}(0.015)$ & $1.244(0.213)$ \\
LAGV - INF & 9.047 & $12.991^{* * *}(0.000)$ & $2.614^{* * *}(0.008)$ \\
FDI - LAGV & 7.756 & $9.668^{* * *}(0.000)$ & $1.506(0.131)$ \\
LAGV - FDI & 7.944 & $10.152^{* * *}(0.000)$ & $1.668^{*}(0.095)$ \\
GOV - LAGV & 1.715 & $3.681^{* * *}(0.000)$ & $2.220^{* *}(0.026)$ \\
LAGV - GOV & 8.245 & $10.927^{* * *}(0.000)$ & $1.926^{*}(0.054)$ \\
\hline
\end{tabular}

Notes: ${ }^{* *},{ }^{* *},{ }^{*}$ shows $1 \%, 5 \%$ and $10 \%$ of significance level. p-values are in parenthesis.

\section{Conclusion and policy implications}

In this study we estimated the short-run effect and the long- run effect of agricultural credits on agricultural productivity by considering a global sample of 53 countries over the period 2000-2018. The long-run estimated coefficients of all variables are all statistically significant while credits to agriculture affects agricultural productivity positively. Furthermore, agricultural credits have a greater impact on agricultural productivity. The short-run dynamic impacts are significant only for government expenditures. Accordingly, the error correction parameter for PMG is significant and negative for government expenditures, which indicates government expenditures discourages agricultural productivity even in the short-run. Furthermore, as it 
can be understood from causality tests, there exists a bidirectional causality between agricultural credits and agricultural productivity, apparently assuming that infrastructure works and incentives to be applied to increase agricultural production indirectly increase the use of agricultural credits.

On the other side, as Swinnen and Gow (1999) argued, credits intended probably for agricultural activities shifted to more profitable sectors. This is in line with intuition of our findings; agriculture credit subsidies provided by governments to agriculture sector might lead to distributive and allocative inefficiencies. In spite of a general weakening of profitability of agricultural investments, pressure on food security and fights against poverty will be driven not only by changes in demand, but by the susceptibility of production to weather and other climatic hazards. In addition to examining short-run and long-run effects and causalities, future research may be conducted to investigate cross-country dynamic interlinkages in greater detail by using sensitivity analysis within the Bayesian Model Averaging framework.

\section{References:}

Anríquez, G., Foster, W., Ortega, J., Falconi, C. \& De Salvo, C.P. (2016). Public expenditures and the performance of Latin American and Caribbean agriculture. IDB Publications (Working Papers), 7839, InterAmerican Development Bank.

Ali, D. A., Deininger, K. \& Duponchel. M. (2014). Credit constraints and agricultural productivity: Evidence from rural Rwanda. Journal of Development Studies, 50(5):649-65. doi:https://doi.org/10.1080/00220388.2014.887687.

Ali, W., Abdullah, A. \& Azam, M. (2017). Re-visiting the environmental Kuznets curve hypothesis for Malaysia: Fresh evidence from ARDL bounds testing approach. Renewable and Sustainable Energy Reviews , 77: 990-1000.https://doi.org/10.1016/j.rser.2016.11.236.

Ben Slimane, M., Huchet-Bourdon, M. \& Zitouna, H. (2016). The role of sectoral FDI in promoting agricultural production and improving food security. International Economics , 145(C), 5065.https://doi.org/10.1016/j.inteco.2015.06.001.

Binswanger, H. (1989). The Policy Response of Agriculture The World Bank Economic Review , 3(1), 231258,https://doi.org/10.1093/wber/3.suppl_1.231

Braverman, A. \& Guasch, J. L. (1986). Rural credit markets and institutions in developing countries: Lessons for policy analysis from practice and modern theory. World Development , 14(10-11),1253-1267.

https://doi.org/10.1016/0305-750X(86)90104-X

Chandio, A., Jiang, Y., Wei, F., Rehman, A., \& Liu, D. (2017). Famers' access to credit: Does collateral matter or cash flow matter? Evidence from Sindh, Pakistan. Cogent Economics 83 Finance , 5, 113.https://doi.org/10.1080/23322039.2017.1369383

Chandio, A.A., Jiang, Y., Rehman, A., \& Akram, A. (2021). Does Formal Credit Enhance Sugarcane Productivity? A Farm-Level Study of Sindh, Pakistan. SAGE Open .https://doi.org/10.1177/2158244020988533

Das, A., Senapati, M., \& John, J. (2009). Impact of Agricultural Credit on Agriculture Production: An Empirical Analysis in India. Reserve Bank of India Occasional Papers , 30, 75-107.

Dumitrescu, E. I. \& Hurlin, C. (2012), Testing for Granger Non-causality in Heterogeneous Panels. Economic Modelling, 29(4), 1450-1460.https://doi.org/10.1016/j.econmod.2012.02.014

Eberhardt, M. (2012). Estimating Panel Time-Series Models with Heterogeneous Slopes. The Stata Journal , 12 (1), 61-71.https://doi.org/10.1177/1536867X1201200105

FAO. 2021. Government expenditures in agriculture 2001-2019. Global and regional trends. FAOSTAT Analytical Brief Series, No. 24. Rome 
Gemmell, N., Kneller, R. \& Sanz, I., (2016). Does the Composition of Government Expenditure Matter for Long-Run GDP Levels? Oxford Bulletin of Economics and Statistics , 78(4), 522-547, 2016.http://dx.doi.org/10.1111/obes.12121

Im, K.S., Pesaran, M.H. \& Shin, Y. (2003). Testing for unit roots in heterogeneous panels. Journal of Econometrics , 115, 53-74.https://doi.org/10.1016/S0304-4076(03)00092-7

Kahan, D. (2013). Market-oriented farming: an overview . Food and Agriculture Organization of the United Nations, Rome. ISBN-13: 978-9251075395

Kao, C. \& Chiang, M.H. (2001). On the estimation and inference of a cointegrated regression in panel data", Baltagi, B.H., Fomby, T.B. and Carter Hill, R. (Ed.) Nonstationary Panels, Panel Cointegration, and Dynamic Panels (Advances in Econometrics, Vol. 15), Emerald Group Publishing Limited, Bingley, pp. 179-222. https://doi.org/10.1016/S0731-9053(00)15007-8.

Kumar, N.N., Patel, A., Chandra, R.A. \& Kumar N.N. (2021). Publication bias and the tourism-led growth hypothesis. PLoS ONE , 16(10): e0258730.https://doi.org/10.1371/journal.pone.025873

Leatham, D. J. \& John A. Hopkin. (1988). Transition in Agriculture: A Strategic Assessment of Agriculture and Banking. Agribusiness, 4 (2),157-165.

DOI:10.1002/1520-6297(198803)4:2<157::AID-AGR2720040205>3.0.CO;2-X

Lopez, C.A., Salazar, L., De Salvo, C.P. (2017). Public Expenditures, Impact Evaluations and Agricultural Productivity: Summary of the Evidence from Latin America and the Caribbean. IDB Technical Note ; 1242.http://dx.doi.org/10.18235/0000627

Luis F. M., Leon J.J., \& Saboya, D. (2007). Cointegration Vector Estimation By Dols For A Three-Dimensional Panel. Borradores de Economia , 474, Banco de la Republica de Colombia.https://doi.org/10.15446/rce.v38n1.48801

Manoharan, N., \& Varkey, R.S. (2021). Agricultural credit and agricultural productivity across Indian states: An analysis.Journal of Public Affairs, https://doi.org/10.1002/pa.2597

Mark, N. \& Sul, D. (2003). Cointegration vector estimation by panel DOLS and long-run money demand. $O x$ ford Bulletin of Economics and Statistics ,65(5), 655-680.https://doi.org/10.1111/j.1468-0084.2003.00066.x

Masih, R. \& Masih, A.M. (1996). Stock-Watson dynamic OLS (DOLS) and error-correction modelling approaches to estimating long-and short-run elasticities in a demand function: new evidence and methodological implications from an application to the demand for coal in mainland China. Energy Economics , 18(4), 315-34.

Misra, R., Chavan, P., \& Verma, R. (2016). Agricultural Credit in India in the 2000s: Growth, Distribution and Linkages with Productivity.Margin: The Journal of Applied Economic Research , 10 (2), 169-197.https://doi.org/10.1177\%2F0973801015625378

Pesaran, M.H. (2004). General Diagnostic Tests for Cross Section Dependence in Panels. Cambridge Working Papers in Economics, No. 435 , University of Cambridge, and CESifo Working Paper Series No. 1229.

Pesaran, M.H. (2007). A Simple Panel Unit Root Test in the Presence of Cross Section Dependence. Journal of Applied Econometrics, 22, 265-312.https://doi.org/10.1002/jae.951

Pesaran, M. H. \& Smith, R.P. (1995). Estimating long-run relationships from dynamic heterogeneous panels. Journal of Econometrics , 68: 79-113.https://doi.org/10.1016/0304-4076(94)01644-F

Pesaran, M. H. \& Shin, Y., (1996). Cointegration and speed of convergence to equilibrium. Journal of Econometrics , 71, 117-143.https://doi.org/10.1016/0304-4076(94)01697-6

Pesaran, M. H., Shin, Y., \& Smith, R. P. (1999). Pooled Mean Group Estimation of Dynamic Heterogeneous Panels. Journal of the American Statistical Association ,94(446), 621-634.https://doi.org/10.2307/2670182 
Pesaran, M.H. \& Yamagata, T. (2008). Testing slope homogeneity in large panels. J. Econometrics, 142, 50-93.https://doi.org/10.1016/j.jeconom.2007.05.010

Rajan, R., \& Ramcharan, R. (2015). The Anatomy of a Credit Crisis: The Boom and Bust in Farm Land Prices in the United States in the 1920s. The American Economic Review , 105 (4), 14391477.https://doi.org/10.1257/aer.20120525

Rehman, A., Abbas Ali Chandio, A.A., Hussain, I., \& Jingdong, L. (2017). Is credit the devil in the agriculture? The role of credit in Pakistan's agricultural sector. The Journal of Finance and Data Science , 3(1-4), 38-44.https://doi.org/10.1016/j.jfds.2017.07.001

Salami, S. \& Arawomo, D. F. (2013). Empirical Analysis of Agricultural Credit in : Any Role for Institutional Factors? African Development Bank Group Working Paper Series . No: 192, African Development Bank, ,

Seven, U., \& Tumen, S. (2020).Agricultural credits and agricultural productivity: Cross-country evidence (IZA Discussion Paper Series No. 12930)

Sriram, M. S. (2007). Productivity of Rural Credit: A Review of Issues and Some Recent Literature. International Journal of Rural Management, 3(2), 245-268.https://doi.org/10.1177/097300520800300204

Stock, J. H. \& Watson, M. W. (1993). A simple estimator of cointegrating vectors in higher order integrated systems, Econometrica, 61, 783-820.https://doi.org/10.2307/2951763

Swinnen, Johan F.M. \& Gow, H.R. (1999). Agricultural credit problems and policies during the transition to a market economy in Central and Eastern Europe. Food Policy, 24(1), 21-47.https://doi.org/10.1016/S03069192(98)00067-0.

Thompson, J. G. (1916). The Nature of Demand for Agricultural Products and Some Important Consequences. Journal of Political Economy ,24 (2), 158-182.http://www.jstor.org/stable/1822553

Tong, T., Yu, T.E., Jensen, K., La Torre Ugarte, D. de \& Cho, S-H. (2016). Impact of Public Infrastructure on Output of U.S. Food Manufacturing Industries: A Heterogeneous Dynamic Panel Approach.Agribusiness , 32(4), 439-453.https://doi.org/10.1002/agr.21455

Tuan Anh, N., Gan, C., \& Anh, D.L.T. (2020). Does credit boost agricultural performance? Evidence from Vietnam. International Journal of Social Economics , 47(9), 1203-1221.https://doi.org/10.1108/IJSE-042020-0238

Tweeten, L., \& Zulauf, C. (2008). Farm price and income policy: lessons from history. Agribusiness, 24, 145-160.https://doi.org/10.1002/agr.20153

Yahyaoui, I. \& Bouchoucha, N. (2021). The long-run relationship between ODA, growth and governance: An application of FMOLS and DOLS approaches.African Development Rev iew, 33: 3854.https://doi.org/10.1111/afdr.12489

\section{Appendix A}

Alphabetical List of the 53 Countries Covered by the Study

Antigua and Barbuda Australia Barbados Belarus Belize Benin Bolivia Botswana Bulgaria Burkina Faso Ca 